\title{
التقابل الداخلي في سفري ارهيا واشعيا
}

התקבולת פנים בספר ירמיהו ובספר ישעיהו: דר'.ריאד עבד אבראהים אל גבורי אוניברסיטת בגדאד מרכז

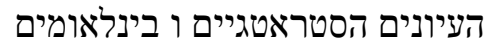

\section{م.د رياض عبد 1براهيم \\ مركز الهراسات الاستراتيهية والدولية جامعة بـغنداد}

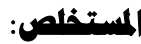

يعد كتاب التوراة احد المصادر المهمة في الدراسات اللغوية والادبية لما يحتويه من بناء لغوي وادبي وفكري وفلسفي .يهتم هذا البحث بدراسة مهمة لاحد العناصر الاساسية الشعر التوراتي , التي تؤلف وحدة متكاملة ومتداخلة يكون فيها البناء اللغوي اساس هذه العناصر المشتركة ـ يتناول هذا البحث قضية التقابل باعتباره احد الاقسام الاساسية اللغوية في بناء النص التوراتي وخاصة الجوانب الادبية واهمها

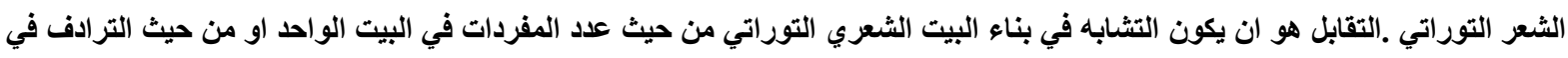

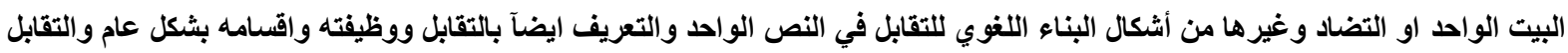

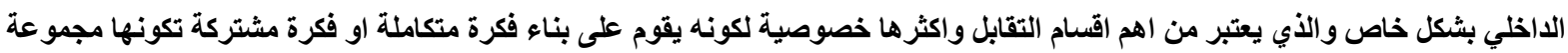
من الابيات الثعرية داخل النص الواحد باسلوب بلاغي وبتعابير وبناء لغوي , حيث تنكون المضمون الواحد بين ابيات شعرية لاتكون مبنية على الصدر والعجز في البيت الواحد بل على الصدر والعجز في بيت شعري اخر او في صدر شعري اخر , بمعتى لاتكون هذه الابيات الثعرية

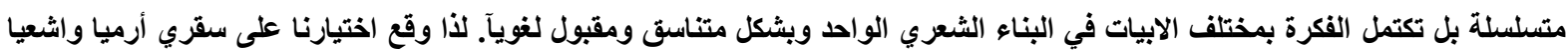
لما يتميزان به من بناء لغوي رصين واسلوب ادبي متميز يكون فيها التقابل الداخلي واضحاَ بشكل مفهوم ومقبول للقاريء.
\end{abstract}

\section{Abstract:}

"The Parallels in books Jeremiah and Isaiah"

By : Dr. Riyadh Abed Ibraheem- Center for strategic international studie- Baghdad university.

The book of The Old Testment is one of the important sources in linguistic and literary studies because it contains linguistic, literary, intellectual and philosophical construction. This research deals with the important study of one of the basic elements of the elements of biblical poetry, which constitute an integrated and overlapping unit in which linguistic construction is the basis of these common elements. This research deals with the issue of encounter as one of the main linguistic divisions in the construction of biblical text, especially the literary aspects and the most important biblical poetry. The encounter peom in terms of the number of vocabulary in the same peom or in terms of synonyms in one line or contrast and other forms of linguistic construction to correspond in the same text and the definition of the addition of the interview and its function and its divisions in general and the internal correspondence in particular, The sections of the interview and the most special because it is based on the construction of an integrated idea or a common idea made by a set of poetic verses within the text in a rhetorical style and expressions and language structure, where the content consists of one of the verses are not based on poetry chest and disability in one line, but on the line of another verse or other poetry, in which these verses are not serialized, but rather complete the idea in different verses in the construction of poetry one in a consistent and acceptable language. Therefore, we chose the book Jeremiah and Isaiah because of its distinctive linguistic construction and a distinct literary style in which the internal encounter is clearly understood and acceptable to the reader.

ספרי ירמיהו וישעיהוו הם מן הספרים הכוללים סוגים חשובים מבחינת הבנין הלשוני הספרותי

והדקדוקי,ראוי לציין כי הספרים הללו שאנו עוסקים בהם כוללים אמצעים מיליציים שונים,לכן זאת הסיבה

החשובה שבחרנו את הספרים על בסיס פירוש אחד הצדדים החשובים מבחינה לשונית התקבולת פנים אחד מסוגי התקבולת שנחשבת מהמורכבים העיקריים בשירה תנכית. התקבולת אחד האמצעים המקובלים בשירה התנכית שמתבסס על משפטים בעלי תוכן מקביל הבאים זה לצד זה،בדרך כלל יש בתקבולת שני משפטים כאלה، אך ייתכן 
להעמיד גם מספר רב יותר של משפטים מקבילים זה אחר זהיהתוכן המקביל עשוי להיות דומה זה לזה، אך ניתן להביא בשני איברי התקבולת גם תכנים הפוכים ומנוגדים.התקבולת פנים שלפנינו שונות הן משאר ההתקבולת: שאנו מוצאים בספר מקרא.המחקר מתענין בבעיה לשונית חשובה לכן המחקר כולל שני פרקים בנוסף למבוא

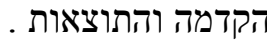

בתחילת המחקר אנו חיבים לדעת את המובן המדויק לתקבולת בצורה כללית מבינת התפקיד החשובית סוגי התקבולת, ונתחיל אחר כך בניתוח לשוני של תקבולת פנים בספרי ירמיהו וישעיהו. התקבולת:אפשר לומר שתקבולת צלעות היא אחד האמצעים הספרותיים הרווחים ביותר בשירה התנכית، שאף

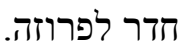
בתקבולת יש בדרך כלל שתי צלעות צלע א' וצלע ב'،ולפעמים שלוש צלעות.השיר התנכי מורכב ממשפטים בעל (3-2) צלעות ולפעמים יותר، ההתקבולת: זו לזו، תקבולת נבחנת בשני מדדים, תוכני וצורני. מבחינה תוכנית התקבולת יכולה להיות נרדפת، ניגדית، וחסרה. מבחינה צורנית התקבולת יכולה להיות מתאימה، חסרה،כיאסטית(מוצלבת) (1) שאילת המחקר:

הבעיה העיקרית במחקר היא התשובה על שאלה חשובה האם התקבולת פנים שונה מן שאר סוגים השונים של התקבולת והאיכיות של השינוי בהבנת התוכן בטקסטי המקרא . מבחינת הלשון והספרות המשנאית. מטרת המחקר: למחקר כמה מטרות חשובות אבל המטרה הראשונה והחשובה היא לדעת או לקביעת את התפקיד לתקבולת פנים בהקמת קשר הדוק בין הצלעות השונות והשפעת שיטה הזאת באיחוד התוכן בכל פרק בספרי המקרא. מבחינה ספרותית ולשונית ביצירת ספרי המקרא. הפתרון: אנחנו מנסים להגיע לפתרון שעיון הלשון והספרות בספרים הקדושים ותבנית הספרים יכולה ויכולה לאיחוד או להציג תוכן משותף על ידי מורכבי התקבולת בצורה כללית ותקבולת פנים בצורה מיוחדת. מילות מפתח: ירמיהו ,ישעיהו ,ספרים ,תקבולת, תקבולת פנים. סוגי התקבולת: לתקבולת ישנם כמה סוגים כמו: א-תקבולת נרדפת، תקבולת שלמה، שבה לכל חלק בצלע הראשונה ישנו חלק בצלע השניה.למשל בספר

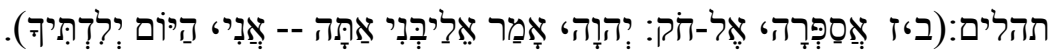


ב-תקבולת נגודית: שבה לכל חלק בצלע הראשונה،מתנגד לחלק בצלע השניה.למשל בספר תהלים: (כיח אֵלֶּה

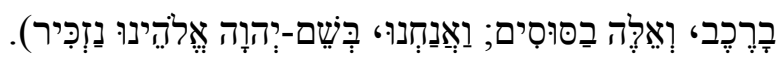

ג-התקבולת פנים: צלעות מקבילות במקבילית יש שני זוגות של צלעות מקבילות מלבן, מעוין וריבוע הם מקרים

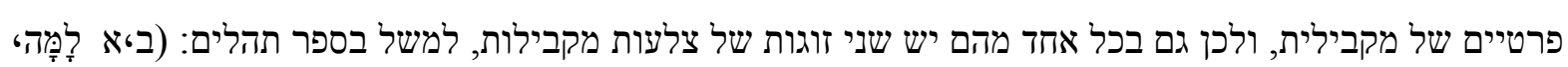

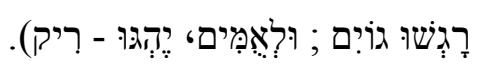

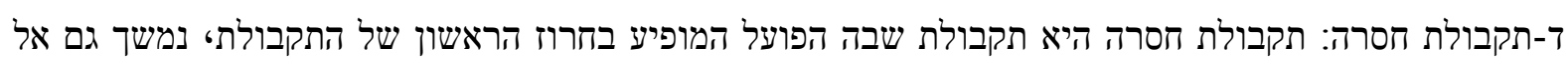

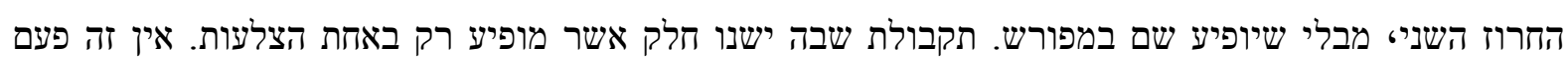

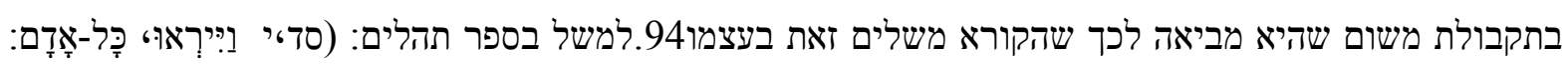

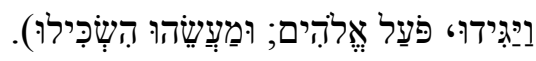

התקבולת פנים: שלפנינו שונות הן משאר ההתקבולת: שאנו מוצאים בספר מקרא, בגלל:

(1) בהיותן התקבולת פנים ולא התקבולת חוץ, כלומר ששני חלקי התקבולת המקבילים זה אל זה הם מאותו

הספר.

(2) שתקבולתן מתבטאת לא כל על-ידי מיליצות וניבים דומים-אלא על-ידי מבנה אחד ותוכן משותף. מובן שלא באו בחשבון להקבלה אותם פסוקים, או חצאי פסוקים, המשמשים פסוק-חוזר, כגון: בספר ירמיהו העל אלה לא אפקד נאם אלוהים ואם בגוי אשר כזה לא תתנקם נפשי- החוזר שלש פעמים: ה, ט, כט, ט, ח. בכל זאת לא שב אפו

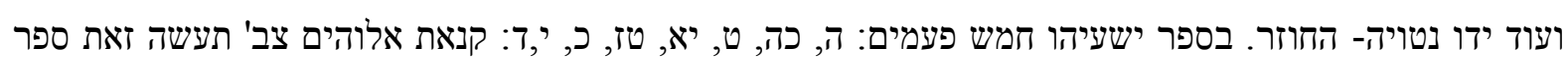

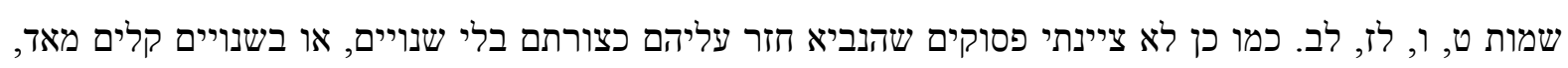

כפי שהם מצויים בשני הספרים שאנו עוסקים בהם בזה, ספרי ירמיהו וישעיהו (2).

פרק ראשון

ספר ירמיתו.

התקבולת הפנים שבספר ירמיהו מתחלקות לפי נושאן ולפי מסגרתן לשתי יחידות, שאנו מביאין אותן בזה בשם

יחידה א ובשם יחידה ב.

יחידה ראשונה:

פרק ב, ט-טז פרק יח, יג-יז הנושא: שתים רעות...

פרק יח

יג.לכן כה אמר ה'

שאלו(2) נא בגוים.

פרק ב

ט.לכן עד אריב אתכם נאם ה'...

'כי עברו כתיים(1) וראו

1.עברו אל כתיים-עברו את הים המפריד ביניכם לבין האיים. ומליצתו היא כמליצת ישעיהו, ובדרך של כיות,

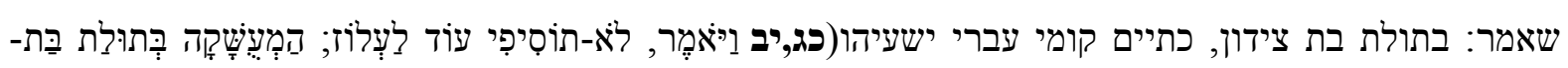




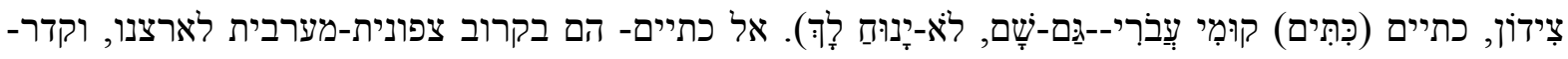
דרומית-מזרחית, ועל כן הם מציינים ארבע רוחות השמים. כיוצא בזה (דברים ד,לב): כי שאל נא לימים ראשונים..ולמקצה השמים ועד קצה השמים. 2.שאלו נא בגוים-הדרישה לשאל חוזרת פעמים אחדות בספר ירמיהו, כאן וכן (ו,טז) עמדו על זרכים וראו ושאלו לנתבות עולם...(ל,ו): שאלו נא וראו... וקדמתו תורה בדבר אמת בלב כי שאל נא לימים ראשונים... ובספר שמות (לב,ז): שאל אביך ויגדך, זקניך ויאמרו לך. ובספר איוב (ח, ח): כי שאל נא לדרך רישון. 3.וקדר שלחו-לעומת שלחו נאמר במקביל: שאלו נא בגוים, כמו כן אנו מוצאים את מתושאל אבי למך מזרע קין בספר בראשית (ד,יח) כמקביל למתושלח אבי למך מזרע שת בספר שמות (ה, כה).להשיב אמרים אמת לשלחיך

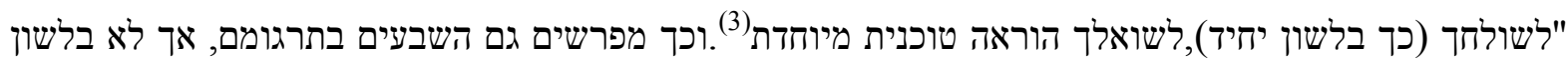
יחיד כי אם בלשון רבים- משום שנוסח המקור העברי שביזם היה לשלחיך, בלשון רבים, כמו שהוא בהרבה כתיבת המקרא ודפוסים לפנינו. ואין להסיק כלל מתרגומם שנוסחתם במקור היתה לשאליך,גם יוכיח שנוסחתו היא לשלחך, כי כך הוא מביא את המלה, ואף-על-פי-כן הוא מבארה: לשאלך. וראיה מכריעה לכך היא העובדא שבכל כתבי-היד והדפוסים שמונה לא נחלקו כלל שהמלה הנדונה היא משורש שלח, ועל מה נחלקו, אם הנוסח הוא

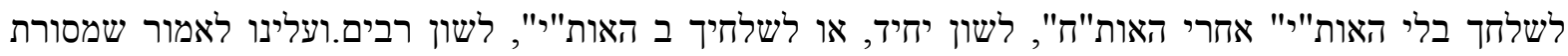
היתה ביד השבעים, וכן היתה ביד המפרשים שלפעמים שאלו ושלחו, הקרובים זה לזה מן הצד האטימולוגי, יש לפעמים משמעות משותפת. ורווגע לנוסח אם בלשון יחיד או בלשון רבים, יש להעיר ששם תואר זה גם בצורת

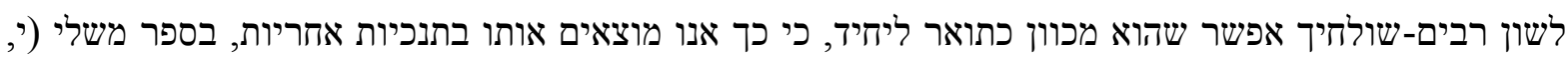
כו): כחמץ לשנים וכעשן לעינים כן העצל לשלחיו (לשלחו). ומפורש יותר בספר שמות (כה, יג): כצנת שלג ביום

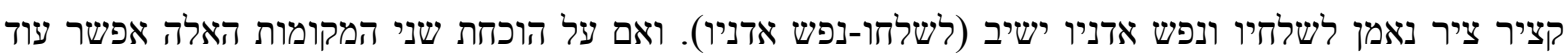
לערער, הרי לך מקום שלישי שאין עליו תשובה וערעור כלל(4). מי שמע כאלה. (4)? (4) היתה כזא

בתולת ישראל !(5)(20) יד.היעזב מצור שדי שלג לבנון,

אם יתנשו מים זרים קרים נוזלים ?(8)
שעררת עשתה מאד

יא.ההימיר גוי אלהים והמה לא אלהים(6)

נאמר בלשון חכמים האומר לשלוחו צא הרוג את הנפש הוא חייב ושולחיו פטור. שמאי הזקן אומר משום חגי הנביא שולחיו חייב (קידושין מג, א), הרי הנושא-שולחיו בלשון ריבוי, והנושא-פטור, חייב בלשון יחיד גם בא

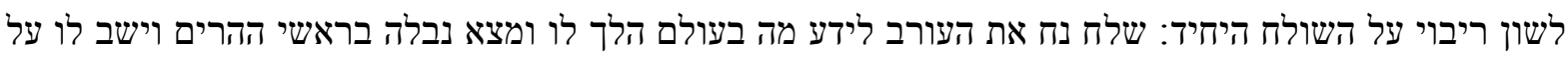
מאכלו ולא השיב שליחותו לשולחיו, וטעמו של דבר משום שהשולח הוא מעין אדון ומצוה לשלוחו, וכמה שנאמר בפסוק שהבאנו: כצנת שלג...ציר נאמן לשלחיו ונפש אדניו ישיב. ואין ספק שמטעם זה גם אמרו בקידושין (מה,

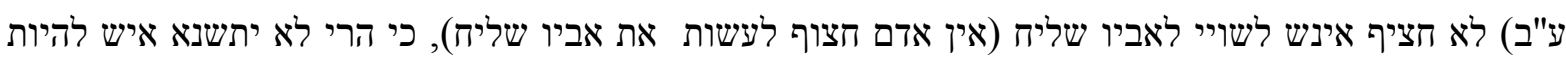
נגיד ומצווה לאביו- ואם אדנות כאן מובן לשון ריבוי שבו, קבע בספר ישעיהו (יט, ד), כי "כל לשון אדנות קרוי בלשון רבים ואפי יחיד",גם בספר בראשית (לה,ז) וכשם שהנביא אמר אדנים קשה (שם ישעיהו), כך אמרו חז"ל: 
שולחיו חייב, שולחיו פטור מעתה מצאנו עוד צד משותף לשלח ושאל, כי גם לשאל יש לפעמים משמעות צווה,גם הראיתי על התקבולת שבין שאל וצווה בישעיהו (מה, יא) האתיות שאלוני על בני ועל פעל ידי תצוני. והתבוננו-

על ידי שלוחיכם, או בדבריהם. וראו-בראית הלב, כמשמעות ולבי(5).

4.הן-מלת השאלה אם, אלא שדרך אם לבוא רק כשאלה שנייה, אלטרנטיבית, אחרי שקדמה לה שאלה והאות השאלה בראשה כגון בפרקנו פסוק לא: המדבר הייתי לישראל, אם ארץ מאפליה), ומשמעות אם-או, ויש הן אם כמלת תנאי והקדמה לשאלה הבאה בהאות השאלה כרגיל, כגון: הן ישלח איש את אשתו.. והיתה לאיש אחר הישוב אליה עוד (ירמיהוג, א) הן היתה כזאת ובמקביל נאמר: מי שמע כאלה ושניהם ממקור אחד יהלכו, למשל בסםר במדבר (ד,לב) הכתוב אמר: כי שאל נא לימים ראשונים...הנהיה כדבר הגדול הזה, או הנשמע כמהו והנה מוצאים הצעת אחד לצרף כאן שתי המלים הן היתה (כזאת) למלה אחת ולקרוא: הנה הנהיתה כזאת אך התקבלות מוכיחה שלא יתכן לעשות כך. אמנם הפסוק בספר דברים היה לנגד עיני הנביא והוא השתמש במליצותיו, אך מה

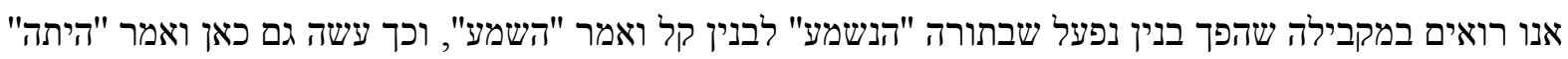
במקום הנפעל ובשניהם הקדים מלת שאלה במקום האות השאלה שבמקרא "הן"-כאן (6). •. ההימיר גוי: ועמי המיר: הראשון הוא משורש ימר והשני משורש מור, ואין הבדל משמעות ביניהם, אלא שכך דרך הרבה משרשי ע"ו, או ע"י, לבוא גם בצורת פ"י,כגון גור-יגור, טוב-יטב, נוק-ינק וכו.. ד. ועמי המיר כבודו בלוא יועיל- הוא מונה בזה שתי רעות, כמפורש בפס' יג. ובתקבולת מקביל אליו חלק ראשון של פסוק (טו: כי) שכחני עמי, לשוא יקטרו, שגם הוא כולל שתי רעות (7). יב. שמו שמים על זאת ושערו חרבו מאד !)(9)

טו. כי שכחני עמי, לשוא יקטרו.(12) ויכשלום בדרכיהם שבולי עולם

ללכת נתיבות דרך לא סלולה.(13)

מדוע היה לבז ?

טז. לשום ארצם לשמה, שרוקת עולם כל עובר עליה ויניד בראשו.
יג. כי שתים רעות עשה עמי: אותי עזבו מקור מים חיים, לחצב להם בארות בארת נשברים(10) אשר לא יכלו המים. יד. העבר ישראל אם יליד בית הוא, טו. עליו ישאנו כפרים, נתנו קולם, וישיתו ארצו לשמה, עריו נצתה מבלי ישב(11). V.שעררת לפי ענינו מקביל חלק זה של הפסוק לפסוק יב שבמקבילה, כי שניהם הם קריאה של תמהון והשתוממות על רוע מעשי העם. ויש בזה מעין מליצה שנחלקן, כי מליצת הנביא בפרק ה, ל היא שמה ושערורה נהיתה בארץ. וכאן בתקבולת חלק את המליצה: בב, יב אמר שמו (פעלבמקום השם שמה) שמים על זאת,ובמקביל אליו אמר שעררת-שערורה. וקרוב להאמר ששעררת נאמרה כנגד ושערו בפסוק המקביל-אף-על-פי- שהאחרון הוא בשעררת שמאל והראשון בשעררת ימין(8). 
8.היעזב מי שהוא, מצור שדי בגלל צור שדה שנקוות עליו טפי מים שאינן נספגות, היעזוב מי שהוא בגלל מים אלו את שלג הלבנון, הטוב והמרענן אם ינתשו ינטשו מים זרים -ממים, בגלל מים זרים, האם בגלל מים כאלה

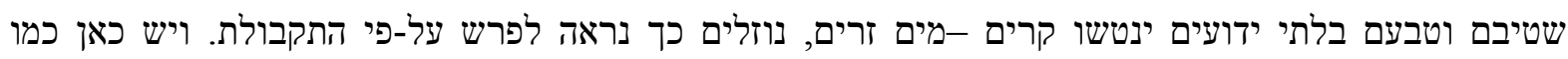
במקבילה שתים רעות ואותו המשלבספר השירים: מעין גנים באר מים חיים ונזלים מן לבנון (שיר השירים ז, טו)

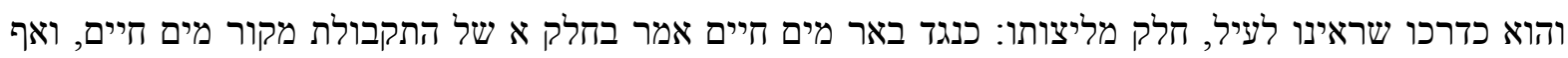
רמז לבאר בכתבו בארות בארת באל"ף, ובחלק ב של התקבולת השתמש במליצות שבסוף אותו הפסוק: ונזלים מן לבנון וידידי מר יהודה הוסיף שלגבי האלהים מתאים יותר הכנוי מקור מאשר באר. 9.הפסוק של קריאת תמהון,כסוף פסוק יג במקבילה. חרבו-רגזו, כאחת המשמעויות של המלחמה, וכן מתרגם לפניו רגזה ארץ רעשו שמים (יואל ב, ')קדמוהי חרובת ארעא זעו שמיא. אך כך הוא מתרגם גם הפעלים אבל, נבל כשהם משרתים מלת ארץ. לפעל אבל השווה ת"י בספר ירמיהו (יב, ד, כג, י) ולפעל נבל תרגום בספר ישעיהו (כד, ד). ולעמת תרגום ליואל הוא מתרגם בספר ישעיהו (יג, יג) על כן שמים ארגיז ותרעש הארץ ממקומה על כן

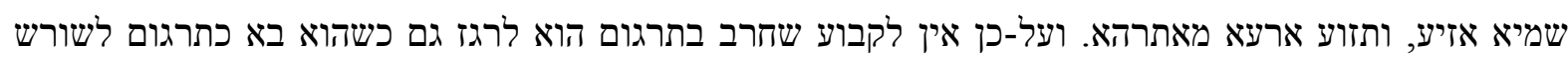

10.לחצב להם בארות, בור שמימיו מכונסים חוצבים בסלע או בקרקע קשה, כדי שלא יספגו מימיו באדמה, וכן הוא אומר בספר דברים (ו,יא) וברת חצובים אשר לא חצבת, וכן בספר דברי הימים ב (כה,'): ויחצב ברות רבים.

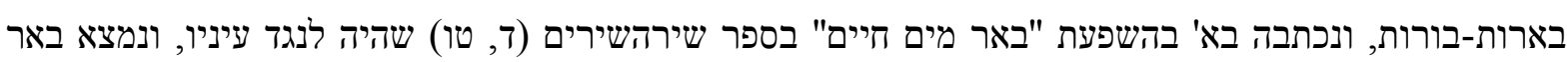
באל"ף וחולם בלשון יחיד שלש פעמים, וכלן בפרק אחד(10). טז. גם בני-נף ותחפנס(14) ירעוך קדקד(15).

ערף ולא פנים אראם(16) בים אידם. יז.כרוח קדים אפיצם לפני אויב.

הנושא: נביאי השקר.

יחידה ביב: פרק כג, ט-כה כט, כא-כד.

דברי ירמיהו כט, כא-כד על הטאם וענשם של שני נביאי השקר שנבאו בקרב גולי יהודה בבבל אשר הגלו עם

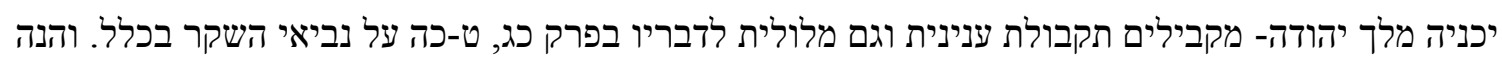
מקבילם בזה:

פרק כג

אל אחאב בן קוליה ואל צדקיהו בן

מעשיה הנבאים לכם בשמי שקר...

והכם לעיניכם. ולקח מהם קללה...
פרק כט

לנבאים נשבר לבי בקרבי...

כי מנאפים מלאה הארץ

כי מפני אלה אבלה הארץ..1

1.עריו נצתה, נצתו קוהלת, משורש יצת, או נצת-נחרבו, נתרוקנו: נצדו (צפניה ג, ו) משורש צדה. גם הכתיב נצתה הוא לשון רבות על דבר בנות צעדה כמו בספר בראשית (מט, כב) . 
ז. ויכשלום- נביאי השקר ואולי: ויכשלום-הם הכשילו אותם-עצמם. בדרכיהם, שהם שבילי עולם-שבילי נצח(11).

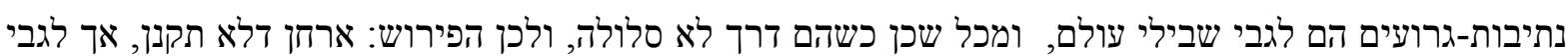
"ארחות עקלקלות" (12)

3. ירעוך קדקד,הפרשנים האחרונים מפרשים ירעוך-ירוצצוך, משורש רעה-רעע, וקדקד-כנרדף לראש כמו שהוא בהרבה מקומות בתנך. אך לפי התקבלות שלפנינו מקביל: "ירעוך קדקד" אל "ערף ולא פנים ארעם" שבמקבילה, ולפי-זה "קדקד" כאן נרדף ל"עורף" והשווה קדל ערף בארמית שעיקר שרשו קד-קדד, שהוא שרשו של קדקד,המסמן את החלק האחורי של הראש ממרומו עד העורף. לפיכך נראה לי לפרש ירעוך קדקד-ירדפוך ערף. רעה-הלך (אחרי מכאן השם רועה לזה שהולך אחרי הצאן) ונרדף הוא לפעל רדף בהושע (יב, ב) אפרים רעה רוח ורדף קדים כל היום כזב ושד ירבה, והשוה (מיכה ב,יא) לו איש הלך רוח ושקר כזב אטף לך ליין ולשכר, ובספר (ישעיהו כט, כד) נאמר וידעו תעי רוח בינה, ושים לב הפעלים הלך,רעה, תעה מצרפים לרוח המתונה בדרך כלל, ורדף מצורף לקדים שהיא עזה וחריפה. 4. ערף: אראם- אראה אותם שהם פונים עורף ונסים לפני אויביהם(13). גם כן:

יען אשר עשו נבלה בישראל וינאפו את נשי רעיהם

וידברו דבר בשמי שקר

אשר לא צויתם,

נאם ה' (כג).

ואל שמעיהו הנחלמי תאמר לאמר (כד).(7)
ובנבאי ירושלים ראיתי שערורה נאוף(2)

והלך בשקר(3)... (יד) לא שלחתי את הנביאים והם רצו, לא דברתי אליהם והם נבאו (כא)(4) אם יסתר איש במסתרים ואני לא יראנו נאם ה'... (כד) שמעתי את אשר אמרו הנבאים הנבאים בשמי שקר(5) לאמר חלמתי חלמתי (כה).

כאן הוא מונה חטאי העם, ובפסוק יד, חטאי נביאי השקר. לחטאי העם השווה הרשימה בספר (ירמיהו ז,ט)

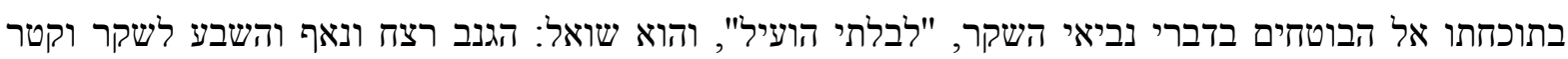
לבעל והלך אחרי אלהים אשר לא ידעתם ובאתם ועמדתם לפני הגוים. וקדמה לו נבואת הושע בסדר שונה קצת, אלה וכחש ורצח וגנב ונאף...על כן תאבל הארץ ואמלל כל יושב בה (הושע ד, ב-ג), והשוה גם בספר (ישעיהו כד, 
2. והלך בשקר-במקבילה: וידברו שקר. 3. צרף לכאן והקבל גם פסוק לב: ואנכי לא שלחתים ולא צויתים . 4. הנבאים בשמי שקר-מקביל לפסוקי (כא וכג) המובאים כאן במקבילה, ולכט, ט, כי בשקר הם נבאים לכם בשמי ואנכי לא שלחתים נאם האלהים. - ועים.

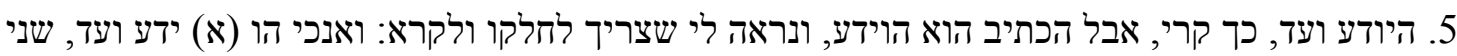

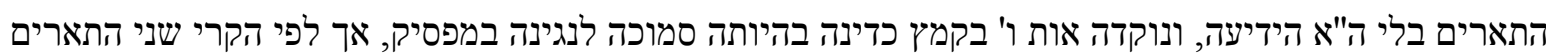
הם בידוע והאות העד כלולה בקמץ ו' החבור(14). 6. התקבלת מוכח הוא מלשון חלום ונקרא כן לפי שהיה חולם להם חלומות שישובו מהרה לירושלים, אך גם המפרש הנחלמי-דמן חלם, כלומר שהיה בן עיר ששמה חלם- צריך לפרש שיש כאן גם השפעת עסוקו כחולם חלומות ולכן נקרא הנחלמי- בצורת נפעל- ולא החלמי כפי שהיה צריך להקרא אלו נקרא רק על שם עירו, אבל נקרא הנחלמי על שם שהיו מחלמים את חולמי החלומות, כמו בספר (ירמיהו כט,ח) (15).

פרק שני

ספר ישעיהו:

בספר ישיעה אנו מוצאים כמה דוגמאות לתקבולת פנים למשל: כי מירושלים תצא שארית 1. 1 כי מציון תצא תורה ופליטה מהר ציון (לז, לב) ודבר ה' מירושלים (ב,ג)

התוכן המשותף כל הטובות באות מציון וירושלים. ויש כאן כיות כיאסמוס כרגיל בהתקבולת, ונוספה בתקבולת, לב מלת הר בשביל המשקל. כי כלה בציר, (.... 2. כי יבש חציר, כלה דשא, אסף בליע יבוא (לב, י) ירק לא היה (טו, ו

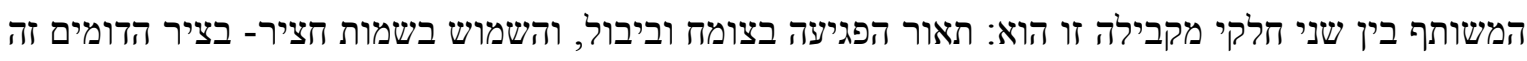
לזה בצלצולם, ובשמוש המשותף בפעל כלה. המליצות האלה חוזרות ונשנות בפי הנביא ואפשר לומר בדרך כיאסטי בפרק (כד, יג) כנקף זית, כעללות אם כלה בציר. ובפרק (מ,ז-ח): יבש חציר, נבל ציץ...לכנקף זית

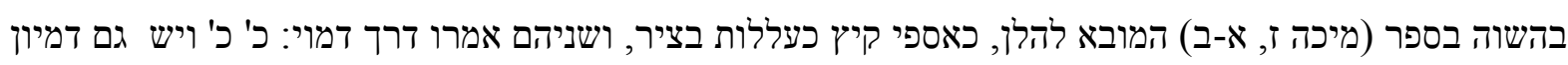

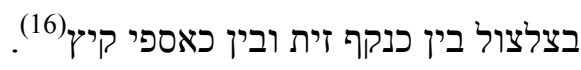
התקבולת-פנים זאת, על שני חליקה, נמצאת גם התקבולת-חוץ. בספר (משלי כז, כה) נתן תאור הפוך מן התאור שבפסוקינו, תאור של צמיחה ופריחה, ונמצאים בו אותם הנושאים, אך בשנוי הפעלים, כמובן, ומשום שטוב מראה עינים הריני מעמידם כאן זה מול זה (17): משלי כז, כה: ישעיהו לב, י: ישעיהו טו, ו: 


כלי יבש חציר,

3 . דומים הם שלשת הפסוקים זה לזה בחומר מליצתם, במבנם ובתכנם. וקרבה יתירה יש בין (ישעיהו טו,ו) לבין הפסוק שבמשלי, כי תכנם הוא למרות נגודם כמעט זהה. בשניהם מדובר על אותו הנושא, על מראה צאן, אלא שבישעיהו מדובר על חרבנו, ובמשלי- על שגשוגו. ובישעיהו לב, י שהדברים מופנים אל הנשים השאננות והבנות

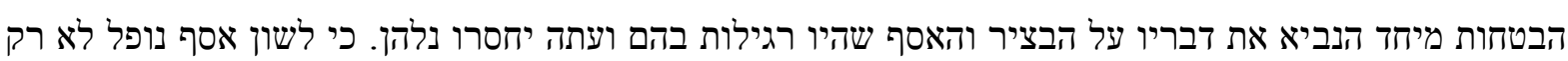

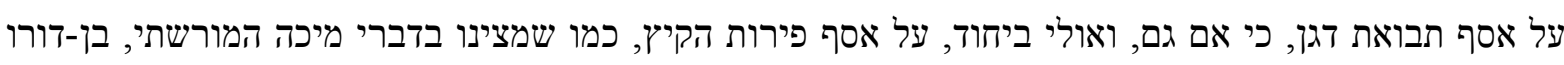
הצעיר של ישעיהוו, המתאונן ואומר בדרך משל ובדרך כיאסטי לדברי ישעיהוו:אללי לי כי הייתי כאספי קיץ. כעללת בציר, אין אשכול לאכול, בכורה אותה נפשי. אבד חסיד מן הארץ, מיכה ז, א-ב ושים לב פסוק א' נאמר בדרך כיות: א-ד: קיץ-בכורה: ב-ג: עללת בציר- אשכול ובמחצית הראשונה של הפסוק הצלעות הן של שתים שתים מלים כל אחת, והמחצית השניה של שלש שלש מלים, וממשיך בשלש גם בנמשל בפסוק ב, ומסיים בארבע(18). 4. ישנם זיקה חזקה בין הפסוק שבמשלי ובין ישעיהו לב,' על ידי שנים משלשה הפעלים שבו: גלה ונאספו. גלה (חציר) שכפעל עומד, בבנין קל, במשמעות גלוי וחשיפה נמצא רק כאן נבחר כנראה, כחקוי לכלה חציר או כלה בציר, שכפי שמסתבר ביו ניבים שגורים בלשון, חקוי חיצוני בצורתו ובצלצולואך במשמעות הפוכה. גם לפעל ונאספו שלפעמים יש לו משמעות של גמר וכליון צריך ליחס גם לו בהקשר שהוא נמצא כאן, משמעות הפוכה.

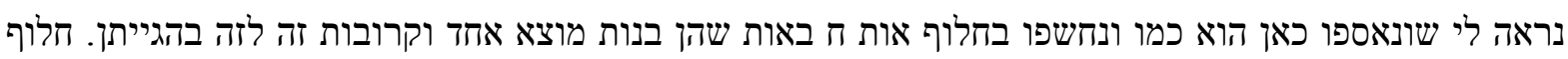

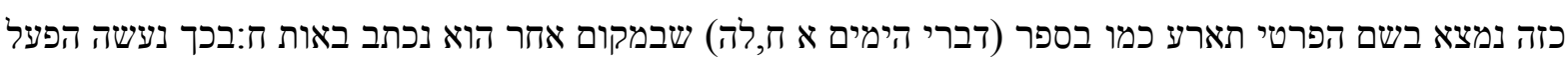

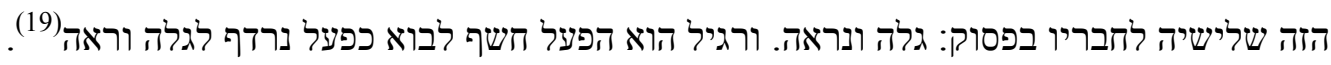
אין ספק גלה נמצא הרבה כפעל עומד במשמעות גלות ונדידה שאף היא לדגש קל אינה אלא לשון גלוי שהרי "כל הגולה יצא מביתו ויגלה לעין רואים ומקום משכנו נעשה חשוף וגלוי, אך מובן זה כבר אינו מרגש בלשון.כך בישעיהו מז, ב-ג: גלי צמתך, חשפי שבל, גלי שוק, עברי נהרות, תגל ערותך גם תראה חרפתך. ובירמיהו יג, כו:

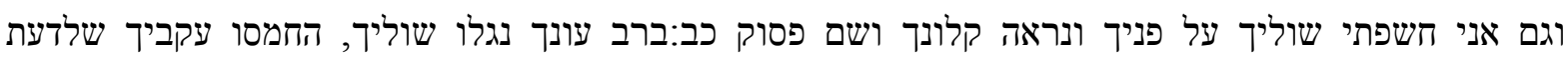
בפירושים חמם הוא חשף בחלוף אות פ באות מ ובשנוי מקומה. ואמנם את שנוי המקום אנו מוצאים גם כשאין

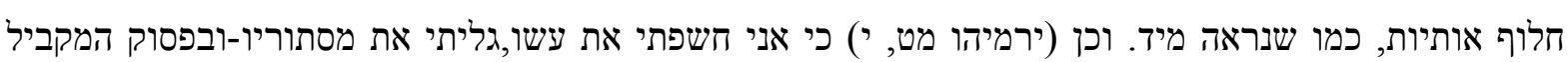
בעובדיה ו נאמר: איך נחפשו עשו, נבעו מצפניו. נחפשו-נחפשו, נבעו-נגלו. גם ישנם צרך לפרש ונאספו במשמעות

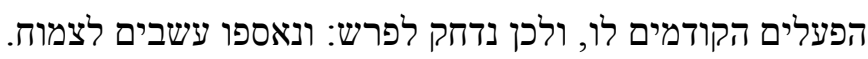
ונראה לי שכשם שהפעל אסף בא לפעמים במקום הפעל חשף, ונאספו פירושו נחשפו, כך גם להפך יש והפעל חשף בא במקום הפעל אסף במשמעותו הרגילה אסף וכנס (כנש), חוקרי הלשון מתבלטים בפתרון "שני חשפי עזים" קשה להם ביחוד לעמוד על הצד האטימולוגי של מלת חשפי בערכו- ולפי דברינו אין חשפי אלא-אספי, שהוא לשון ריבוי של אסף מילת אסיפה וקבוץ, וחשפי עזים הם "קבוצי עזים". אמנם אינם מנמקים את פירושים. 
גם מוסיפים ואומרים "ואין לו דמיון", אך נתקיים בו: תמת ישרים תנחם. ואולי גם חשף-מים, (ישעיהו ל, יד)חרש לחתות אש מיקוד ולחשף מים מגבא, ענינו אסף מים ונבחר לשון לחשף משום שהוא דומה בצלצולו למלת לחתות שהוא מקביל לה. וכן גם חשף יין בחגי ב, טז:..בא אל היקב לחשף חמשים פורה משמעותו מעיקרו אסף, שהתפתח למשמעות שאב. ואנו מוצאים את הפעל אסף משרת מים בדברי האשה התקועית,כמו בספר (שיר השירים ב יד, יד) כי מות נמות וכמים הנגרים ארצה אשר לא יאספו. אך אפשר שרק על "מים נגרים", רדודים ופזורים, נופל לשון אסף אבל לא על מים, או נוזלים אחרים, כשהם מכונסים ונקוים. ויתכן שזהו הגון המבדיל בין אסף

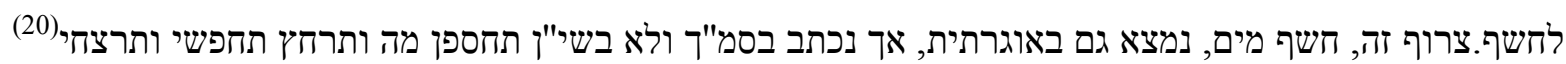

$$
\text { 5. כי אפס המץ, כלה שד,אסיף }
$$

נעשה להפך,התרגום חשפתי בירמיהו מלשון חפוש ובלוש ארי אנא איתיתי בלושין על עשו,בתרגום כך דרך לשון נקיה כלפי מעלה. ובעקבותיו אחירים הולכים שתרגום חשפתי בצית (בדקתי). ולשון ארמית נבעו נתבקשו וכו'.גם כן נחלקו בפירוש של מבעה, מפרוש מלשון בקוש ומפרוש מלשון גלוי. הפירושים של המפרשים ונאספו מילת אסיפה:והעשבים יאספו עמך למאכל הצאן, אבל אם כך היה צריך לאמר ואספת כמו שהוא באמת בתרגום השבעים, כי הרי-שלא כמו גלה ונראה-הם אינם נאספים מאליהם. ועוד שעשבות

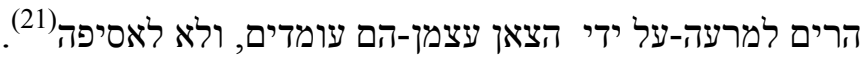
המשותף בחלק הראשון של שני הפסוקים הוא לא רק במבנה ובתוכן, כי אם גם בשימוש המשותף בפעלים אפס

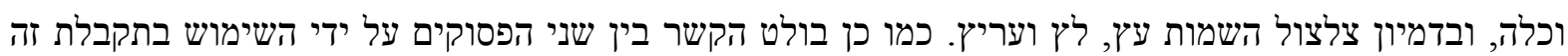

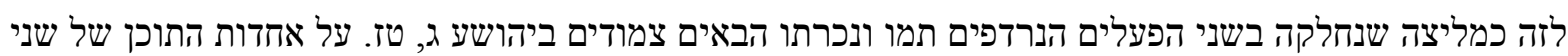
פסוקי המקבילה הזאת, ולפיכך אף תרגם את שניהם תרגום זהה ורק בסופי הפסוקים שינה את פירושם לפי שוניים במקור.רעיון אחר פירוש שונה ומקורי לפסוק זה (טז, ד). לדעתו מכוונים כל הדברים שבפסוק אל מואב, וארץ

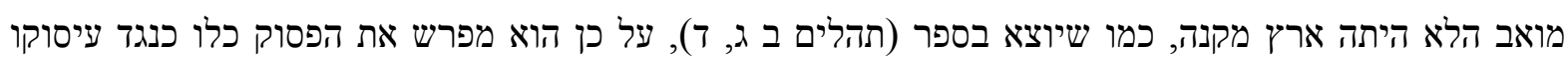

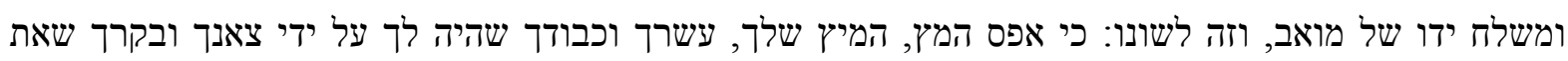

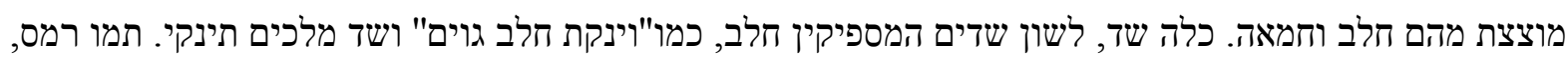

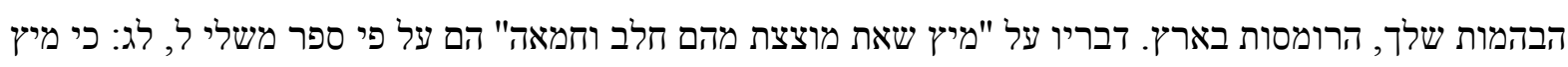

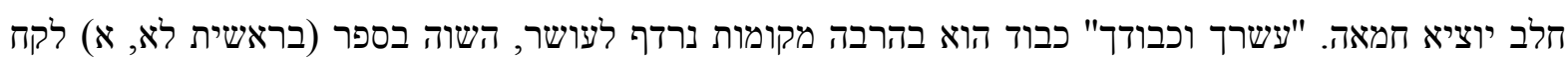

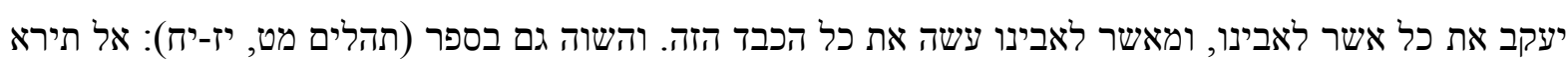

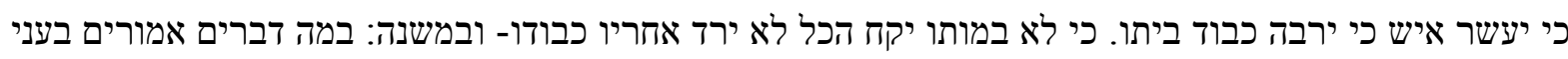

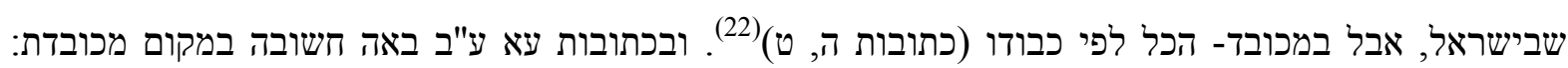
בעשירות- שכן אשה חשובה וכו'. שכידוע אינו כלל ממיתרי מלים, מה ראה להוסיף ל"עשרך" שם נרדף זה אלא רמז רמז לנו בו, דרך אגב, כדרכו בהרבה מקומות, על פסוק שיש בו ללמד על הענין המדובר, על מצץ, חלב, שדשד, ויניקה, והוא ישעיהו סו, יא: למען תינקו ושבעתם משד תנחמיה, למען תמצו והתענגתם מזיז כבודב (שעור הכתוב הוא: למען תינקו משד תנחמיה ושבעתם, למען תמצו מזיז כבודה והתענגתם-ורויתם), בפסוק יב: וכנחל 
שוטף כבוד גוים וינקתם.. כבוד-שפע, וכאן בעיקר שפע נוזל, ולכן דימיו "כנחל שוטף", ונופל בו לשון יניקה,

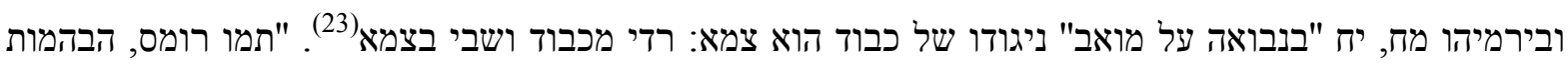
הרומסות בארץ" בגלל תמו שהוא לשון רבים-רבות מפרש רש"י מלת רמס, כמו שכבר אמרנו, כשם כולל בלשון ריבוי. ואולי יש לצרף לרמס אות מ"ם ממלת מן שלאחריה, ותהי המ"ם עולה ויורדת, ונקרא: תמו רמסם מן הארץ. לתמו מן הארץ השוה תהל' קד, לה: יתמו חטאים מן הארץ, לרמיסת הבהמות השוה בספר (ישעיהו ז,כה):והיה למשלחת שור ולמרמס זה. הקריאה רמסם מקבלת חזוק מן העובדה שגם הפסוק המקביל, כט, כ, מתחיל בלשון יחיד וגומר בל' רבים(24). לפי פשוטם שלבפירושם זה, מדובר בטז, ד על מכה כלכלית, על כליון משק הרפת של מואב, ולפי זה אין לפסוק זה ולפסוק כט, כ, שהצבנו כמקביל לו, תוכן משותף, ותקבלתם היא חיצונית בלבד.כי תאור הפגיעה בצומח שבאותו פסוק כמשל, ואלה דבריו: כי יבש חציר, כלומר גבוריהם ומלכיהם ושליטיהם, מסביר אם כן למה הוא מדבר על חציר ודשא וגו' "ולפי ששבחה של ארץ מואב הוא מראה הטוב שבה כמו ששנינו אילים ממואב (תוספתא מנחות ט, יג) לפיכך משל את פורענותה בחורבן מרעה שלה. ויש להניח שהדברים נאמרו גם לגבי פסוקנו, והוא מקביל אפוא לכט, כ גם בתוכן(25). רעיון אחר בפירוש טז, ד מלת מן הארץ שישנה במקור העברי, וכך לשונו: ספו כל דהוו דישין ארעא. אך צריך לדעת שרושמי שנויי הנוסח של לא הראו על נוסח בלי מלת מן. היא גם נתגרמה על ידי השבעים ועל ידי האחרים.

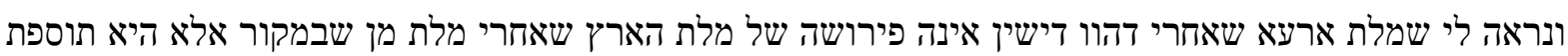

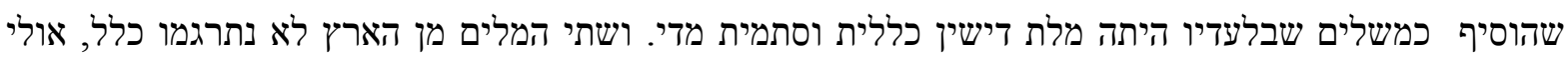
בגלל קושי הסגנון לאמר ספו כל דהוו דישין ארעא מן ארעא. גם אני מוסיף מלת בארץ ואומר תמו רומס, הבהמות הרומסות בארץ. ומסתבר שאין בארץ אלא משלים(26). 6. ואמר ביום ההוא אמרו לנמהרי לב:

הז-

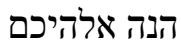

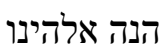
חזקו אל תיראו, קוינו לו--נקם יבוא גמול אלהים....

$$
\text { הוא יבוא וישעכם (לה, ד) }
$$$$
\text { ויושיענו... (כה, ט) }
$$

מקבילה זו שונה מן הקודמות במבנה ובמשקל, היא גם אינה מתחילה במלת כי כמותן, אך כל זה, דומני, אינו

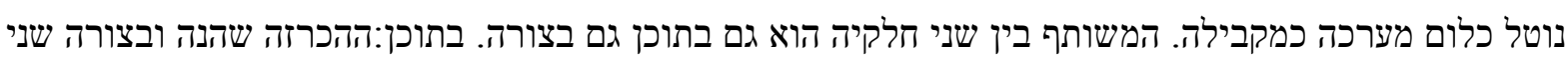
החלקים מתחילים באמירה וגומרים נפלאים (27).

תוצאות: 1- התקבולת אחד האלמנטים החשובים ביותר בלשון והספרות המקראית בעל ספרי המקרא ובספרי ירמיהו וישעיהו בצורה מיוחדת . 2- ספרי ירמיהו וישעיהו כוללים סוגים לשוניים ספרותיים ודקדוקים, בגלל הספרים הללו נכתבו בשיטה לשונית מיליצית מיוחדת לכן בחרתי בהם במחקר שלי. 
3- התקבולת פנים מתבטאת לא כל על-ידי מיליצות וניבים דומים-אלא על-ידי מבנה אחד ותוכן משותף. מובן

שלא באו בחשבון להקבלה אותם פסוקים, או חצאי פסוקים, המשמשים פסוק-חוזר . 4- לתקבולת ישנם כמה סוגים כמו:תקבולת נרדפת•תקבולת נגודית,תקבולת שלמה، שבה לכל חלק בצלע הראשונה ישנו חלק בצלע השניה. 5- התקבולת פנים: צלעות מקבילות במקבילית יש שני זוגות של צלעות מקבילות מלבן, מעוין וריבוע הם מקרים פרטיים של מקבילית, ולכן גם בכל אחד מהם יש שני זוגות של צלעות מקבילות

הערות שולים:

1- א . מ. הברמן, כתב לשון וספר , פרקי עיון, , ירושלים , עמ"144-149.

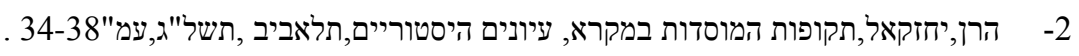

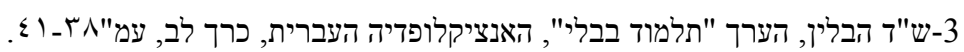

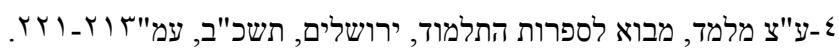

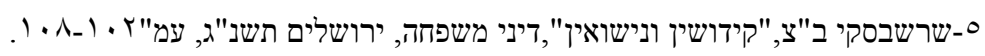

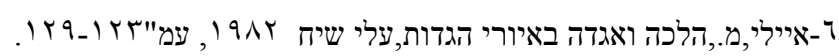

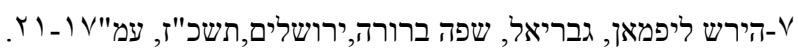

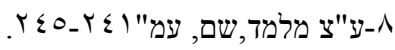

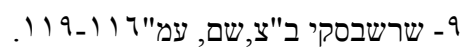

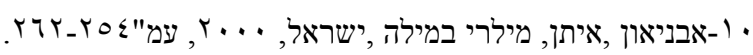
11 ו-1)

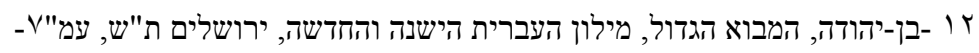

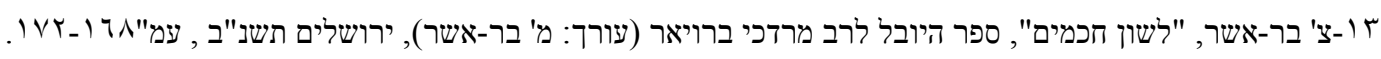

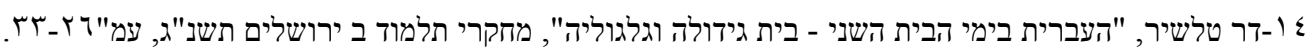

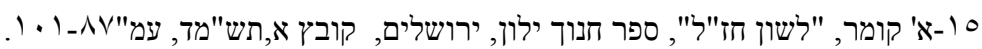

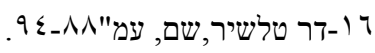

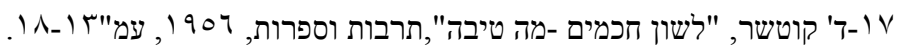

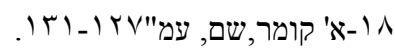

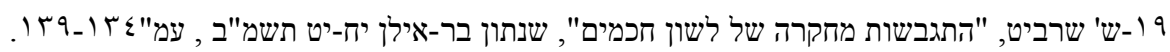

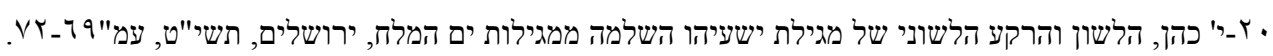

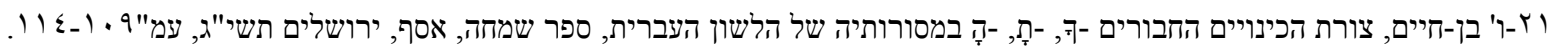

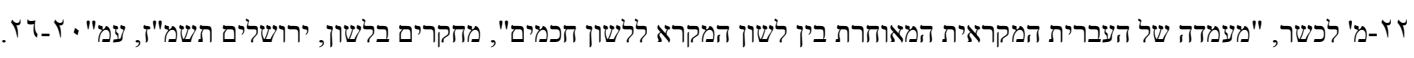

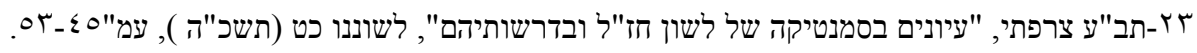

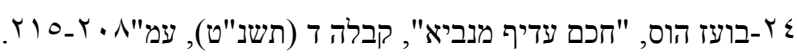

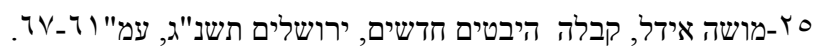

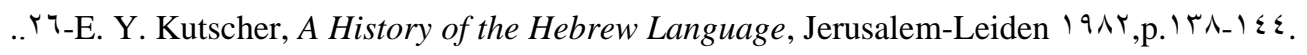
. r v-M. H. Segal, Mishnaic Hebrew and its Relation to Biblical Hebrew and to Aramaic, JQR ( $19 \cdot 1)$,p. 19-9r.

מקורות:

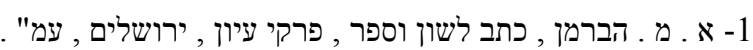

2- הרן,יחזקאל,תקופות המוסדות במקרא, עיונים היסטוריים,תלאביב ,תשל"ג.

3-ש"ד הבלין, הערך "תלמוד בבלי", האנציקלופדיה העברית, כרך לב.

§-ע"צ מלמד, מבוא לספרות התלמוד, ירושלים, תשכ"ב. 
-שרשבסקי ב"צ, "קידושין ונישואין", דיני משפחה, ירושלים תשנ"ג.

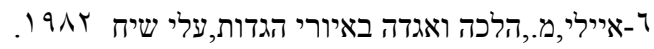

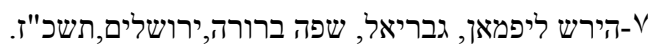

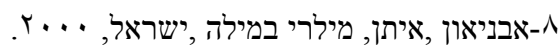
9 • ו-צ' בר-אשר, "לשון חכמים", ספר היובל לרב מרדכי ברויאר (עורך: צ' בר-אשר), ירושלים תשנ"ב . ו-1-דר טלשיר, "העברית בימי הבית השני - בית גידולה וגלגוליה", מחקרי תלמוד ב ירושלים תשנ"ג.

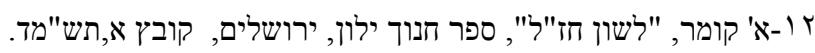
זו-ד' קוטשר, "לשון חכמים -מה טיבה",תרבות וספרות, 1907 ו 19.

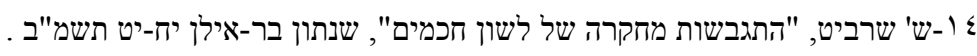
10-18' כהן, הלשון והרקע הלשוני של מגילת ישעיהו השלמה ממגילות ים המלח, ירושלים, תשי"ט.

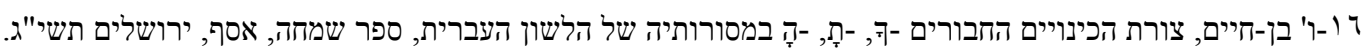
Vו-מ' לכשר, "מעמדה של העברית המקראית המאוחרת בין לשון המקרא ללשון חכמים", מחקרים בלשון, ירושלים תשמ"ז. ג 1-תב"ע צרפתי, "עיונים בסמנטיקה של לשון חז"ל ובדרשותיהם", לשוננו כט (תשכ"ה ) .

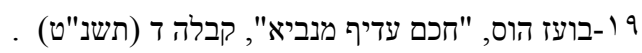

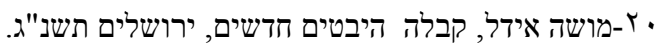

.21 .E. Y. Kutscher, A History of the Hebrew Language, Jerusalem-Leiden $19 \wedge$ r, . r T-M. H. Segal, Mishnaic Hebrew and its Relation to Biblical Hebrew and to Aramaic, JQR ( 19.1),

\section{סיכום:}

המחקר התענין בספרי ירמיהו וישעיהוו הם מן הספרים הכוללים סוגים חשובים מבחינת הבנין הלשוני הספרותי

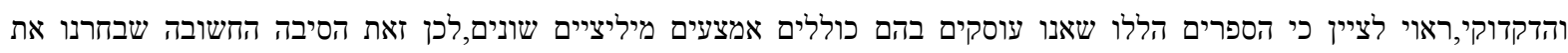
הספרים על בסיס פירוש אחד הצדדים החשובים מבחינה לשונית התקבולת פנים אחד מסוגי התקבולת שנחשבת מהמורכבים העיקריים בשירה תנכית. התקבולת אחד האמצעים המקובלים בשירה התנכית שמתבסס על משפטים בעלי תוכן מקביל הבאים זה לצד זהיבדרך כלל יש בתקבולת שני משפטים כאלהי אך ייתכן להעמיד גם מספר רב יותר של משפטים מקבילים זה אחר זהיהתוכן המקביל עשוי להיות דומה זה לזה، אך ניתן להביא בשני איברי התקבולת גם תכנים הפוכים ומנוגדים.התקבולת פנים שלפנינו שונות הן משאר ההתקבולת: שאנו מוצאים בספר מקרא,בגלל מתבטאת לא כל על-ידי מיליצות וניבים דומים-אלא על-ידי מבנה אחד ותוכן משותף. מובן

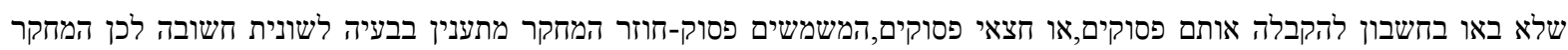
כולל שני פרקים בנוסף לתקציר הקדמה סיכום והתוצאות . בחור 